\title{
VARIETAL RESPONSE OF TOMATO (Lycopersicon esculentum Mill) TO TIME OF FERTILIZER APPLICATION
}

\author{
${ }^{*}$ Falodun E.J and Adewunmi S.A.
}

Department of Crop Science, Faculty of Agriculture, University of Benin, Nigeria.

*Corresponding author: ehizogie.falodun@uniben.edu

\section{ABSTRACT}

Field experiments were carried out during the 2015/16 and 2016/17 dry cropping seasons at the Experiment Farm of the Faculty of Agriculture, University of Benin, Benin City. The study was a $2 \times 4$ factorial fitted into a randomized complete block design (RCBD) in three replications. Two tomato varieties (Roma savannah and UC82) and four times of fertilizer application (T1: all fertilizer applied at 2 weeks after transplanting (2WAT), T2: 1/2 of the fertilizer applied at 2WAT and 1/2 at flowering, T3: one third 1/3 applied at 2WAT, 1/3 at flowering, $1 / 3$ at fruiting and T4: all fertilizer applied at flowering) were used. In both years, stem diameter, number of flowers, fruits and fruit weight/plant $(\mathrm{kg} / \mathrm{ha})$ and yield were significantly improved by Roma savannah. Fruit diameter $(5.70 \mathrm{~cm}$ and $4.75 \mathrm{~cm})$ increased with UC82 compared with Roma savannah which produced the lowest fruit diameter $(3.95 \mathrm{~cm}$ and 3.11 $\mathrm{cm}$ ). Roma savannah had a higher fruit yield of $8.59 \mathrm{tha}^{-1}$ and $7.24 \mathrm{t} \mathrm{ha}^{-1}$ compared with 5.99 t ha- ${ }^{-1}$ and 4.57 t ha- $^{-1}$ produced by UC82. In 2016/17 cropping season T3 and T4 significantly improved stem diameter above other treatments and T2 and T4 produced highest fruit yields which were similar. However, in both years highest fruit yields (10.39 tha-1 and $\left.7.09 \mathrm{t} \mathrm{ha}^{-1}\right)$ were consistent with T2. The use of Roman savannah variety and T2 treatment should be encouraged for tomato production, in terms of higher fruit yield in this locality.

Key words: flowers, fruits, cropping seasons, Roma savannah, UC82 


\section{INTRODUCTION}

In Nigeria, tomato (Lycopersicon esculentum Mill) is grown for their edible fruits. The crop is the second most consumed vegetable worldwide after onions and pepper. Tomato is an excellent source of vitamins, minerals, and antioxidants which help control cancer, health disease as well as improve the general health of man. Studies on epidemiology have proved that tomato fruits contain high amounts of antioxidants such as carotenoids, polyphenols, ascorbic acid and many others (Perveen et al., 2015). Wang et al. (2020) revealed that lycopene which is an antioxidant found in tomato fruit has chemoprotective properties against oral cancer. The annual production of fresh tomatoes on a global scale amounts to approximately 160 million tonnes (FAO, 2016). Africa production in 2018 for tomato cultivation was about 20.78 million tonnes of which Nigeria production was estimated at 3.91 million tonnes (FAO, 2018). In comparison, three times more potatoes and six times more rice grown around the world (FAO, 2016). Despite its importance and drive towards increased tomatoes production, the necessity to meet consumers demand has not been realized in Nigeria. The high cost of tomato in the Nigerian market justifies that the production is far lower than the demand. Some of the factors that contribute to low tomato yield in Nigeria are the use of unimproved varieties, low soil fertility and unfavourable soil physical properties. Lack of high yielding varieties combined with low nutrient status of the soil attributes is major constraints in tomato production in the tropics. Adenuga et al. (2012) attributed the low usage of inorganic fertilizer in some parts of the country to the educational status of farmers, farm size and contact with extension workers. Optimal growth of tomato can be achieved with the use of high yielding varieties and right fertilizer applied at the right time, according to the growth stage and phenology of the tomato plant. Non-judicious use of fertilizer has also been a problem plaguing tomato production. Excessive chemical fertilizers are applied to assure high yield. However, over fertilization could cause decline of tomato yield and quality, decrease in the efficiency of nutrient use, soil degradation, increased accumulation of heavy metal in soil (Yang et al., 2017) and increase in water pollution by soil nitrate leaching and runoff losses (Kuscu et al., 2014). Yang et al. (2018) stated that basal application of excessive urea may lead to soil consolidation and salinization and soil aggregates reduction. However, inadequate fertilizer use would inevitably compromise crop yield. Crop yield is one of the principal factors that determine optimal fertilization practices (Thakur et al., 2020). Proper nutrient management and other improved agronomic practices can help tomato producers to meet the demand. Fixen and Reetzs (2006) established that fertilizer best management practices are based on the concept of applying the fertilizer at the right rate, time and place. This implies that the exogenous nutrient for optimum yield must be applied as near as possible to the time the crop needs them in order to achieve optimum crop use efficiency and minimize its potential for environmental 
pollution. There is dearth of information on research findings suggesting suitable fertilizer management plan for tomato production, knowledge of this will be helpful for improving fertilizer recommendations and for achieving sustainable production in tomato. Therefore, the objective of this study was to examine the growth and fruit yield of tomato varieties to time of fertilizer application in Edo rain forest agro-ecological zone of Nigeria.

\section{MATERIALS AND METHODS}

\section{Description of Experimental Area}

The experiment was conducted in 2015/16 and 2016/17 dry cropping seasons of November to March at the Departmental Farm of Crop Science, University of Benin, Benin City, Nigeria and Lies within the geographical coordinates of $\left(5045^{\prime \prime}\right.$ and 7034 "N) and Longitude (5004" and $6045 " \mathrm{E}) 88 \mathrm{~m}$ above sea level. The climate is tropical and the vegetation is lowland rainforest in the south (with mean annual rainfall of $2300 \mathrm{~mm}$ ) to guinea savanna in Edo North with 1400 $\mathrm{mm}$ mean rainfall. The dry season generally extends from November to March. During this period, rainfall drops drastically to less than $19.0 \mathrm{~mm}$ in any of the months. Temperatures show some variations throughout the years, with average monthly temperature varying between $24^{\circ} \mathrm{C}$ and $33.5^{\circ} \mathrm{C}$. The soil is characterized by an ultisol derived from coastal sediments.

\section{Soil Analysis}

The experimental field was manually cleared and debris worked into the soil. Prior to planting, composite soil samples were collected from a depth of $0-30 \mathrm{~cm}$, using soil auger. Samples were air-dried in laboratory, ground, sieved through a $2 \mathrm{~mm}$ sieve, packaged and analysed for its routine soil physical and chemical properties using standard laboratory procedures outlined by Mylaravapus and Kennelley (2002). The pH meter was used to determined soil pH. The results of the soil analysis are presented in Table 1.

\section{The Study Design}

The study was a $2 \times 4$ factorial fitted into a randomized complete block design (RCBD) in three replications. The treatments were composed of two tomato varieties (Roma savannah and UC82) and four times of NPK 15:15:15 fertilizer application at the rate of $400 \mathrm{~kg} \mathrm{ha}^{-1}$, (T1: all fertilizer applied at 2 weeks after transplanting (2WAT), T2: half $1 / 2$ of the fertilizer applied at 2 WAT and at flowering, T3: one third 1/3 applied at 2 WAT, 1/3 at flowering, 1/3 at fruiting and T4: all fertilizer applied at flowering). Tomato seeds of Roma savanna and UC 82B were obtained from National Institute for Horticultural and Research (NIHORT). The experimental plot was manually cleared and the debris worked into the soil. Nursery beds were prepared, tomatoes seeds were sown in the beds. The seedlings were raised under shades made from palm fronds for four weeks. The field was marked for laying out and divided into plots each measuring $3 \mathrm{~m} \times 1.8 \mathrm{~m}$ two weeks before transplanting. Each replicate had 8 plots for a total of 
24 plots. Treatments were assigned to each experimental unit randomly. Four weeks old tomato seedlings were transplanted to the field at a spacing of $60 \mathrm{~cm} \times 60 \mathrm{~cm}$, to give 15 plants per plot and a total plant population of 27,777 plants ha- ${ }^{-1}$. Plots were mulched with dry grasses to conserve moisture and weeding was carried out 2 and 6 weeks after transplanting (WAT).

\section{Data Collection}

Four plants were randomly tagged per plot for data collection. Data collection started at 4 WAT and commenced until 7 WAT for the vegetative characters. Parameters measured were plant height $(\mathrm{cm})$, number of leaves, number of branches, leaf area $(\mathrm{cm})$ and stem diameter $(\mathrm{cm})$ while data on number of flowers, number of fruits, fruit fresh weight $(\mathrm{g})$, fruit diameter $(\mathrm{cm})$ and fruit yield $\left(t \mathrm{t}^{-1}\right)$ were taken between 8 - 15 WAT

\section{Statistical Analysis}

Data were analysed with analysis of variance (ANOVA) using a General linear model (GLM) of statistical analysis system (SAS 2002). Differences in means were compared using Least Significant Difference (LSD) at $\mathrm{P} \leq 0.05$.

\section{RESULTS}

The experimental site was sandy loam and the pre-cropping chemical and physical analysis of the soil sample showed that the soil was slightly acidic with $\mathrm{pH}$ of 5.50 (Table 1). The soil sample was low in essential nutrients $\mathrm{N}\left(0.04 \mathrm{~g} \mathrm{~kg}^{-1}\right)$ and $\mathrm{P}\left(5.52 \mathrm{mg} \mathrm{kg}^{-1}\right)$ while $\mathrm{K}(0.30 \mathrm{cmol}$ $\mathrm{kg}^{-1}$ ) was slightly higher compared with the critical concentration values of $2.50 \mathrm{~g} \mathrm{~kg}^{-1} \mathrm{~N}, 30 \mathrm{mg}$ $\mathrm{kg}^{-1} \mathrm{P}$ and $0.20 \mathrm{cmol} \mathrm{kg}^{-1} \mathrm{~K}$ for optimum crop production (Mangale et al., 2016).

Table 1: Physico-chemical analysis of the soil sample used

\begin{tabular}{ll}
\hline Soil properties & Values \\
\hline $\mathrm{pH}\left(\mathrm{H}_{2} \mathrm{O}\right)$ & 5.50 \\
Organic matter $\left(\mathrm{g} \mathrm{kg}^{-1}\right)$ & 11.52 \\
Total $\mathrm{N}\left(\mathrm{g} \mathrm{kg}^{-1}\right)$ & 0.04 \\
Available $\mathrm{P}\left(\mathrm{mg} \mathrm{kg}^{-1}\right)$ & 5.52 \\
Exchangeable $\mathrm{K}\left(\mathrm{cmol} \mathrm{kg}^{-1}\right)$ & 0.38 \\
Exchangeable $\mathrm{Ca}\left(\mathrm{c} \mathrm{mol} \mathrm{kg}^{-1}\right)$ & 0.92 \\
Exchangeable $\mathrm{Mg}\left(\mathrm{c} \mathrm{mol} \mathrm{kg}^{-1}\right)$ & 0.37 \\
Sand $(\%)$ & 88.70 \\
Silt $(\%)$ & 4.50 \\
Clay $(\%)$ & 6.80 \\
Textural class & Sandy loam \\
\hline
\end{tabular}


There were significant differences on some vegetative characters of tomato plant as influenced by the varieties (Tables 2$)$. In both years, Roman savannah increased stem diameter $(0.38 \mathrm{~cm})$ above UC82 $(0.31 \mathrm{~cm})$ variety Similarly, in 2016/17 cropping season, Roman savannah significantly $(P \leq 0.05)$ increased the number of branches and leaf area $\left(8.26\right.$ and $\left.100.83 \mathrm{~cm}^{2}\right)$ compared with UC82 variety which produced $\left(6.38\right.$ and $\left.90.01 \mathrm{~cm}^{2}\right)$ respectively (Tables 2 and 3).

Table 2: Effects of time of fertilizer application on some vegetative characters of two varieties of tomato (2015/2016) and (2016/2017) dry cropping seasons

\begin{tabular}{|c|c|c|c|c|c|c|}
\hline \multirow[b]{2}{*}{ Treatments } & \multicolumn{3}{|c|}{ 2015/2016 Cropping season } & \multicolumn{3}{|c|}{ 2016/2017 Cropping season } \\
\hline & $\begin{array}{l}\text { Plant } \\
\text { height } \\
\text { (cm) }\end{array}$ & $\begin{array}{l}\text { Number } \\
\text { of } \\
\text { leaves }\end{array}$ & $\begin{array}{l}\text { Number } \\
\text { of } \\
\text { branches }\end{array}$ & $\begin{array}{l}\text { Plant } \\
\text { height } \\
\text { (cm) }\end{array}$ & $\begin{array}{c}\text { Number } \\
\text { of } \\
\text { leaves }\end{array}$ & $\begin{array}{l}\text { Number } \\
\text { of } \\
\text { branches }\end{array}$ \\
\hline \multicolumn{7}{|l|}{ Varieties } \\
\hline Roman & $41.72^{\mathrm{a}}$ & $70.38^{a}$ & $14.52^{\mathrm{a}}$ & $32.26^{a}$ & $59.70^{a}$ & $8.26 \mathrm{a}$ \\
\hline \multicolumn{7}{|l|}{ Savannah } \\
\hline UC 82 & $43.87^{a}$ & $78.85^{a}$ & $16.06^{a}$ & $29.42^{a}$ & $48.65^{a}$ & $6.38^{b}$ \\
\hline Significance & Ns & Ns & Ns & Ns & Ns & * \\
\hline Lsd & 5.10 & 24.46 & 4.77 & 4.46 & 14.15 & 1.16 \\
\hline \multicolumn{7}{|l|}{$\begin{array}{l}\text { Time of } \\
\text { application }\end{array}$} \\
\hline $\mathrm{T} 1$ & $39.91^{b}$ & $63.54^{a}$ & $12.12^{a}$ & $29.03^{a}$ & $60.01^{a}$ & $7.51^{\mathrm{a}}$ \\
\hline $\mathrm{T} 2$ & $40.12^{b}$ & $72.50^{a}$ & $14.37^{a}$ & $27.61^{a}$ & $57.44^{a}$ & $7.33^{a}$ \\
\hline T3 & $43.79 \mathrm{ab}$ & $75.25^{b}$ & $16.33^{a}$ & $33.36^{a}$ & $54.82^{a}$ & $7.70^{a}$ \\
\hline $\mathrm{T} 4$ & $47.37^{a}$ & $87.17^{b}$ & $18.30^{a}$ & $22.62^{a}$ & $45.32^{a}$ & $6.85^{a}$ \\
\hline Significance & * & Ns & Ns & Ns & Ns & Ns \\
\hline $\begin{array}{l}\text { Lsd } \\
\text { Interaction }\end{array}$ & 7.21 & 34.59 & 6.75 & 2.02 & 19.99 & 1.64 \\
\hline $\mathrm{V}^{*} \mathrm{~T}$ & Ns & Ns & Ns & Ns & Ns & Ns \\
\hline
\end{tabular}


Table 3: Effects of time of fertilizer application on some vegetative characters of two varieties of tomato (2015/2016) and (2016/2017) dry cropping seasons

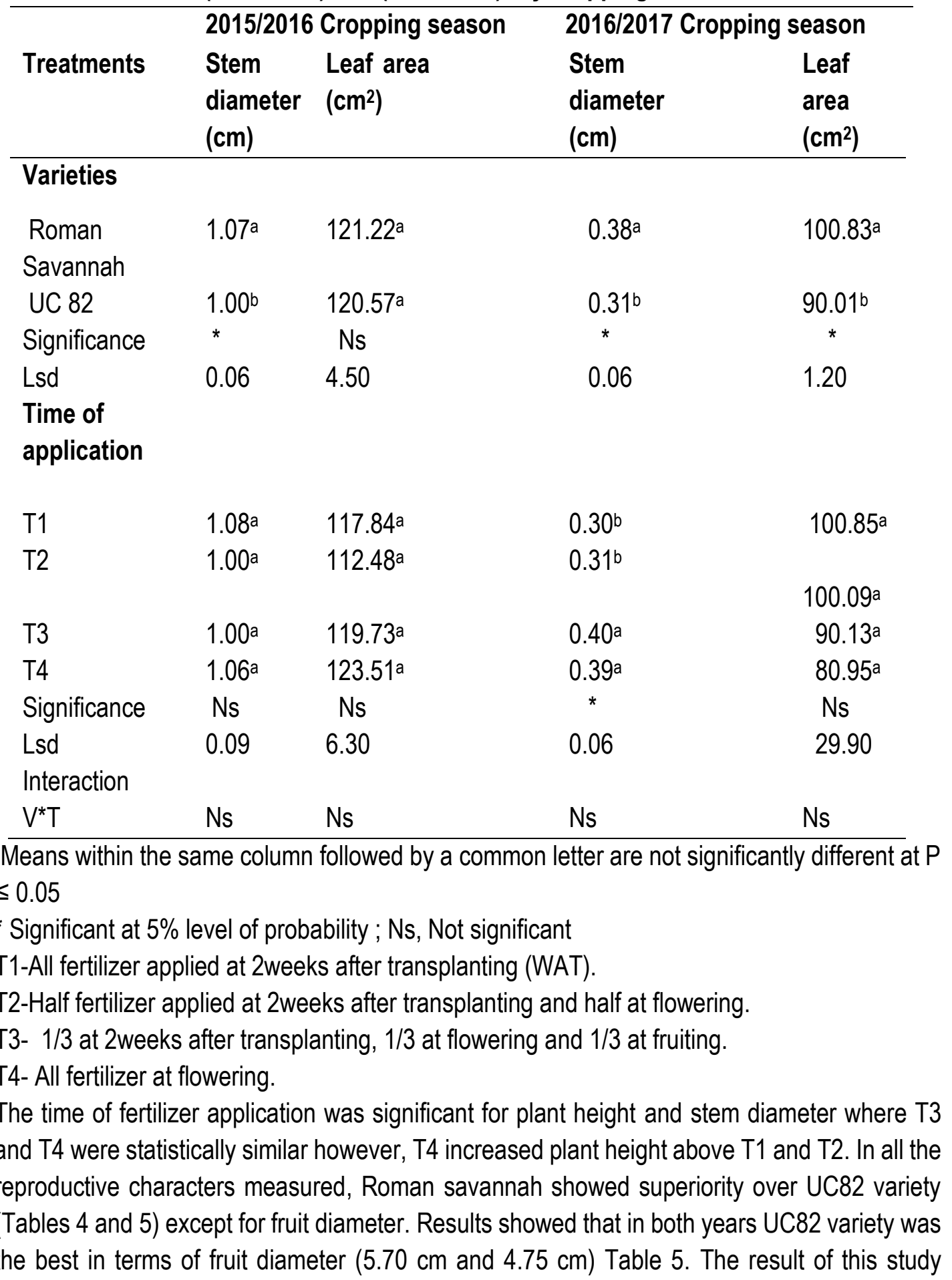


showed similar trend in the number of fruits / plant for T2 and T4 in both years. The number of fruits/plant were significantly higher in T2 and T4 compared with T1 and T2 which recorded significantly lower values. In 2016/17, T2 and T4 produced significantly similar and higher number of flowers and fruits (13.47 and 6.70) and (13.43 and 6.67) respectively (Table 4). Fruit weight ( $345.14 \mathrm{~kg} \mathrm{ha}^{-1}$ and $338.10 \mathrm{~kg} \mathrm{ha}^{-1}$ ) was highest in T2 while similar fruit yield (7.09 tha$\left.{ }^{1}\right)$ and (6.88 $\left.\mathrm{t} \mathrm{ha}^{-1}\right)$ were produced at T2 and T4 respectively. However, in 2015/16 cropping season T2 significantly produced highest fruit weight (454.83 $\left.\mathrm{kg} \mathrm{ha}^{-1}\right)$ and yield (10.39 kg ha-1) above all other treatments measured (Table 5).

Table 4: Effects of time of fertilizer application on some reproductive characters of two varieties of tomato (2015/2016) and (2016/2017) dry cropping seasons

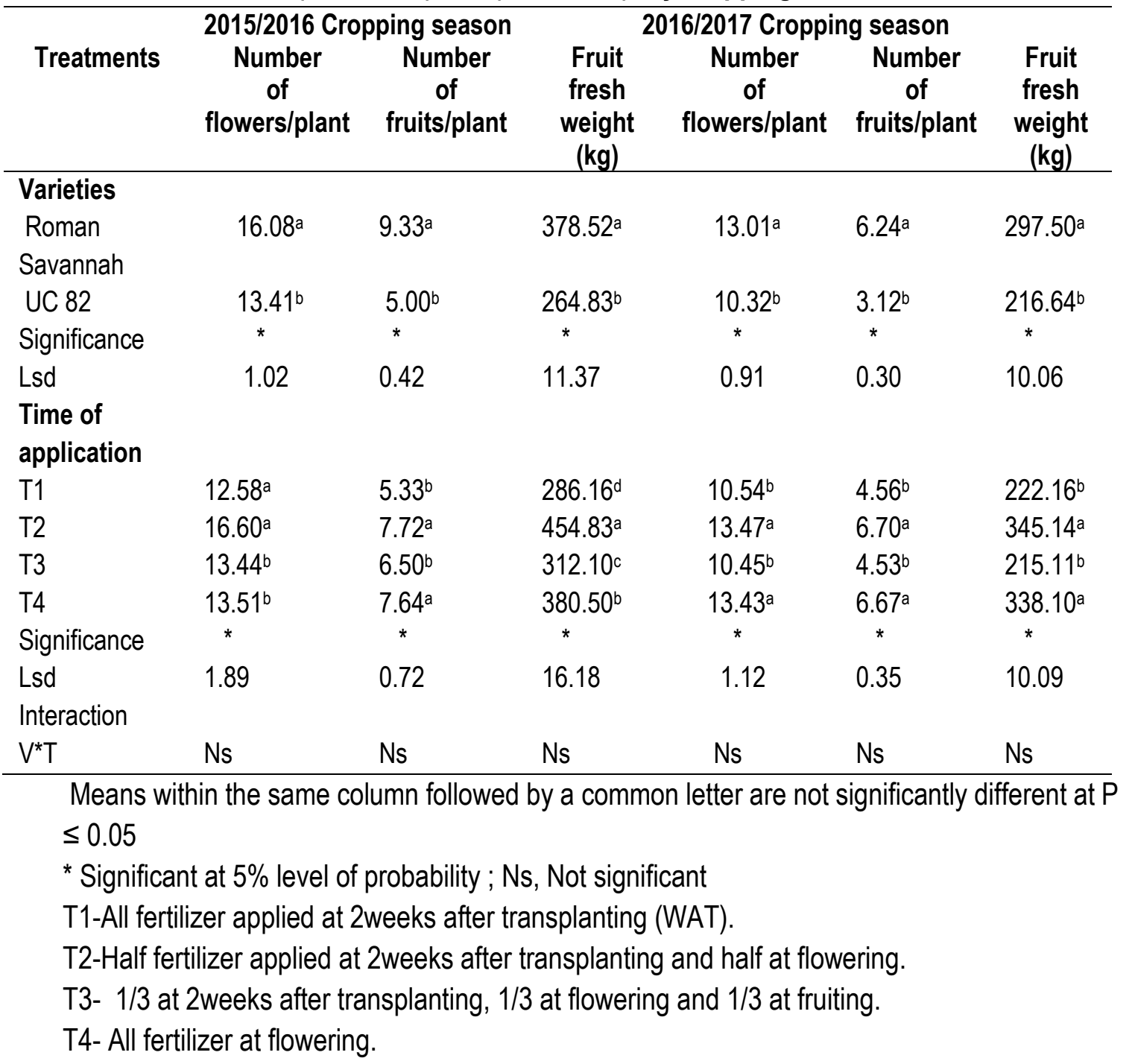


Table 5: Effects of time of fertilizer application on some reproductive characters of two varieties of tomato $(2015 / 2016)$ and (2016/2017) dry cropping seasons

\begin{tabular}{|c|c|c|c|c|}
\hline \multirow[b]{2}{*}{ Treatments } & \multicolumn{3}{|c|}{ 2015/2016 Cropping season } & \multirow{2}{*}{$\begin{array}{l}\text { 2016/2017 Cropping season } \\
\text { fruit } \\
\text { er } \quad \begin{array}{l}\text { yield } \\
\left(\mathrm{t} \mathrm{ha}^{-1}\right)\end{array}\end{array}$} \\
\hline & $\begin{array}{l}\text { fruit } \\
\text { diameter } \\
\text { (cm) }\end{array}$ & $\begin{array}{l}\text { fruit } \\
\text { yield } \\
\text { (t ha- } \\
\text { 1) }\end{array}$ & $\begin{array}{l}\text { fruit } \\
\text { diameter } \\
(\mathrm{cm})\end{array}$ & \\
\hline \multicolumn{5}{|l|}{ Varieties } \\
\hline $\begin{array}{l}\text { Roman } \\
\text { Savannah }\end{array}$ & $3.95^{b}$ & $8.59^{a}$ & $3.11^{b}$ & $7.24^{a}$ \\
\hline UC 82 & $5.70^{a}$ & $5.99 \mathrm{~b}$ & $4.75^{\mathrm{a}}$ & $4.57^{b}$ \\
\hline Significance & * & * & * & * \\
\hline $\begin{array}{l}\text { Lsd } \\
\text { Time of } \\
\text { application }\end{array}$ & 0.47 & 0.47 & 0.37 & 0.40 \\
\hline T1 & $4.08^{b}$ & $5.75^{c}$ & $3.98^{b}$ & $4.10^{b}$ \\
\hline $\mathrm{T} 2$ & $6.53^{a}$ & $10.39 a$ & $4.96^{a}$ & $7.09 a$ \\
\hline T3 & $4.13^{b}$ & $5.73^{c}$ & $4.04^{b}$ & $4.18^{b}$ \\
\hline T4 & $4.56^{b}$ & $7.29 \mathrm{~b}$ & $4.53^{a}$ & $6.88^{a}$ \\
\hline Significance & * & * & * & * \\
\hline $\begin{array}{l}\text { Lsd } \\
\text { Interaction }\end{array}$ & 0.66 & 0.67 & 0.54 & 0.61 \\
\hline $\mathrm{V}^{*} \mathrm{~T}$ & Ns & Ns & Ns & Ns \\
\hline
\end{tabular}

Means within the same column followed by a common letter are not significantly different at $P$ $\leq 0.05$

* Significant at $5 \%$ level of probability ; Ns, Not significant

T1-All fertilizer applied at 2weeks after transplanting (WAT).

T2-Half fertilizer applied at 2weeks after transplanting and half at flowering.

T3- $1 / 3$ at 2 weeks after transplanting, $1 / 3$ at flowering and $1 / 3$ at fruiting.

T4- All fertilizer at flowering. 


\section{DISCUSSION}

The physicochemical values of the experimental site were lower than the critical values established by Mangale et al. (2016) for $\mathrm{N}$ and $\mathrm{P}$, except $\mathrm{K}$ which was high. Hence the need for exogenous nutrient in order to enhance optimum growth and yield of tomato. The poor fertility status may be connected to continuous cultivation of the soil over the years. Falodun and Edafe (2020) asserts that for good yield and better quality of vegetable crops fertilizers should be applied to soils of poor nutrient status at the recommended rates. Soil fertility is a major overriding constraint that affects all aspects of crop production. The low fertility status of the soil could be due to intense precipitation with its associated erosion and leaching of soil nutrients in the environment. The positive response in some of the vegetative and in all of the reproductive character observed in Roman savannah variety compared with UC82 supports the findings of Falodun and Emede (2019) who in their work reported the superiority of Roman savannah especially in yield attributes when compared with UC82 and Roman VF varieties and this may be attributed to genetic make-up of the varieties tested. Isah et al. (2014) attributed the growth and yield differences of crop varieties to physiological process which is controlled by interplay of both genetic make-up and the environment. Olaniyi et al. (2010) evaluated the growth attributes in tomato varieties and found that higher growth attributes were associated with UC82 than other varieties tested. The increase in stem diameter of UC82 when compared with Roma Savannah agrees with the work of Miras et al. (2011) which reported UC82 superiority in stem diameter to other varieties tested while the pronounced effect of variety on leaf area supports earlier work of Ojiako et al. (2018) who reported that variety had influence on leaf area of okra plant. The significant differences in yield parameters may probably be as a result of differences in the times of applied nutrients as yield parameters are sensitive to adequate nutrient supply. The lower yield associated with $\mathrm{T} 1$ (all fertilizer applied at 2 weeks after transplanting) could be due to the loss of nutrients required by crops through leaching by irrigation water before the critical nutrient requirement stage of the plant since the fertilizer was applied as a single dose. The observed lower yield of $\mathrm{T} 3$ (1/3 at 2 weeks after transplanting, $1 / 3$ at flowering and $1 / 3$ at fruiting) could possibly be due to the fact that the nutrient was not sufficient to be applied in three split doses. The increase in yield and yield attributes especially with T2, (half fertilizer applied at 2 weeks after transplanting and half at flowering) could probably be due to the fact that the fertilizer was sufficient and spilt applied at the time the plants needed it, at initial stage as starter of vegetative growth and later at development thereby boosting nutrient availability and preventing fertilizer loss to the environment through leaching and volatilization. This supports the finding of Wabela (2018) who reported the highest yield of tomato fruits when $50 \%$ of urea fertilizer was applied at transplanting time and $50 \%$ at development period. Marschner (2012) reported that balanced supply of fertilizers, in the correct quantity and time, is a fundamental factor for maximum expression of the production 
potential of tomato hybrids. Clain et al. (2013) reported that effective placement and timing of fertilizers can maximize both yield and nutrient use efficiency of crops, by increasing net profit for the producer. The yield increase reported with T4 (Applying all fertilizer at flowering) in 2016/17 cropping season suggests that the flowering stage of any plants is a critical stage for nutrient requirement and applying nutrients at this stage could be beneficial to tomato plant. This result supports the finding of Hokam et al. (2011) who concluded that later application of fertilizer in the growing stages of tomato favours fruit development.

\section{CONCLUSION AND RECOMMENDATION}

The growth and yield parameters of tomato varieties were influenced by the time of fertilizer application. In terms of variety, UC82 produced larger fruit diameter than Roman savannah. However, Roman savannah proved superior to UC82 in term of fruit yield per hectare, producing significantly highest fruit yield (8.59 tha-1 and $7.24 \mathrm{t} \mathrm{ha}^{-1}$ ) which was $17.83 \%$ and $22.93 \%$ higher than UC82 variety in both years. Although applying fertilizer at T4 (applying all fertilizer at flowering) favoured tomato fruit yield, highest fruit yield was consistent with T2, (half fertilizer applied at 2 weeks after transplanting and half at flowering) in both years. The use of Roman savannah variety and T2 (half fertilizer applied at 2 weeks after transplanting and half at flowering) should be recommended for tomato production, in terms of higher fruit yield in this study area.

\section{REFERENCES}

Adenuga, A. H., Omotesho, K. F., Olatinwo, K. B., Muhammad-Lawal, A. \& Fatoba, I. (2012). Determinants of fertilizer usage in dry season amaranthus vegetable production in Kwara State, Nigeria. Agrosearch, 12 (2), 126-134.

Clain, J., Brand, D.B., Rick, E., Don, H., \& Kathrin, O.R. (2013). Factors affecting nitrogen fertilizer volatilization. EBO208, Extension Publication at Motana state University. Retrieved from http://landresources.montana.edu/soilfertilityl

Falodun, E.J. \& Emede, T.O. (2019). Influence of plant spacing on the growth and yield of tomato (Lycopersicon esculentum Mill.) varieties. Agrosearch, 19(1), 46-58. https://dx.doi.org/10.4314/agrosh.v19i1.4

Falodun, E.J. \& Edafe, V.E. (2020). Productivity, nutrient concentration, uptake and quality of Amaranthus (Amaranthus cruentus $L$.) as influenced by cutting heights and fertilizer type. Notulae Scientia Biologicae, 12(3), 719-728. DOI: https://dx.doi.org/10.15835/nsb12310754

FAO (Food and Agriculture Organization of the United Nations), (2016). Tomato Production statistics. Faostat.fao.org. accessed on $26^{\text {th }}$ of June 2020 
Fixen, P.E. \& Reetz, H, F. (2006). Fertilizer best management practices - Making the best better. Better Crop, 90 (2), 3-7

Hokam, E. M., El-Hendawy, S. E. \& Schmidhalter, U. (2011). Drip Irrigation Frequency: The Effects and their Interaction with Nitrogen Fertilization on Maize Growth and Nitrogen Use Efficiency under Arid Conditions. Journal of Agronomy and Crop Science, 197, 186-201

Isah, S., Amans, E.B., Odion, E.C. and Yusuf, A.A. (2014). Growth Rate and Yield of Two Tomato Varieties (Lycopersicon esculentum Mill) under Green Manure and NPK Fertilizer Rate Samaru Northern Guinea Savanna, International Journal of Agronomy, 932759, 8-10. https://doi.org/10.1155/2014/932759.

Wabela, K. (2018). Effects of Split Application of Nitrogen Fertilizer on Furrow Irrigated Tomato Production. Journal of Natural Sciences Research, 8(11), 19-22.

Kuscu, H., Turhan, A., Ozmen, N., et al. (2014). Optimizing levels of water and nitrogen applied through drip irrigation for yield, quality, and water productivity of processing tomato (Lycopersicon esculentum, Mill.). Horticulture, Environment and Biotechnology, 55:103-114.

Mangale, N., Muriuki, A., Kathuku-Gitonga, A.N. Kibunja, C.N., Mutegi, J.K., Anthony O. Esilaba, A.O., Ayuke, F.O., Nguluu, S.N. and Gikonyo, E.W. (2016). Manual for Integrated Soil Fertility Management in Kenya, 107pp.

Marschner, P. (2012). Marschner's mineral nutrition of higher plants. Academic press, 649p.

Miras, R. D., Hossain T., Sultana M.M., Golam Sarwar S.H.M. and Safiar Rahman M.D. (2011). Variation in growth and yield quality of tomato varieties under different sowing time. Bangladesh Research publication Journal , 6 (1): 72-76.

Olaniyi, J. O., Akanbi, W.B. Adejumo, T.A. and Akande, O.G. (2010). Growth, fruit yield and nutritional quality of tomato varieties. African Journal of Food Science, 4 (6), 398-402,

Ojiako, F. O., Ibe, A. E., Ogu, E. C. and Okonkwo, C. C. (2018). Effect of varieties and mulch types on foliar insect pest of okra [Abelmoschus Esculentus L. (Moench)] in a humid tropical environment. Agrosearch, 18 (2): 38 - 58

Perveen R., Suleria H.A., Anjum F.M., Butt M.S., Pasha I., Ahmad S. (2015). Tomato (Solanum lycopersicum) carotenoids and lycopenes chemistry; metabolism, absorption, nutrition, and allied health claims A comprehensive review. Critical Review of Food Science and Nutrition, 55 (7): 919-929.

Statistical Analysis System (SAS). (2002). SAS/STAT User's Guide. Version 8, 6th edition. SAS Institute, Cary. NC

Thakur, A.K., Mandal, K.G. and Raychaudhuri, S. (2020) Impact of crop and nutrient management on crop growth and yield, nutrient uptake and content in rice. Paddy Water Environment, 18: 139-151. https://doi.org/10.1007/s10333-019-00770-x 
Wang, R., Lu, X. and Yu, R. (2020). Lycopene Inhibits Epithelial-Mesenchymal Transition and Promotes Apoptosis in Oral Cancer via PI3K/AKT/m-TOR Signal Pathway. Drug

Design, Development and Therapy, 24 (14): 2461-2471. doi: 10.2147/DDDT.S251614. PMID: 32606612; PMCID: PMC7321693.

Yang, Q., Liu, J. and Zhang, Y. (2017). Decoupling Agricultural Nonpoint Source Pollution from Crop Production: A Case Study of Heilongjiang Land Reclamation Area, China. Sustainability, 9 (6): 1-11 https://doi.org/10.3390/su9061024

Yang XD, Ni K, Shi YZ, et al. (2018). Effects of long-term nitrogen application on soil acidification and solution chemistry of a tea plantation in China. Agriculture, Ecosystems and Environment. 252:74-82. 